\title{
Three-dimensional tumor cell cultures employed in virotherapy research
}

This article was published in the following Dove Press journal:

Oncolytic Virotherapy

\author{
Linus D Kloker' \\ Can Yurttas ${ }^{2}$ \\ Ulrich M Lauer ${ }^{1,3}$ \\ 'Department of Clinical Tumor \\ Biology, University Hospital, \\ University of Tübingen, Tübingen, \\ Germany; ${ }^{2}$ Department of General, \\ Visceral and Transplant Surgery, \\ University Hospital, University \\ of Tübingen, Tübingen, Germany; \\ ${ }^{3}$ German Cancer Consortium \\ (DKTK), German Cancer Research \\ Center (DKFZ), Tübingen, Germany
}

Correspondence: Ulrich M Lauer Internal Medicine VIII, Department of Medicine, University Hospital Tübingen, University of Tübingen, 10 OtfriedMüller-Strasse, Tübingen 72076, Germany Tel +4970712983190

Fax +49707 I294686

Email ulrich.lauer@uni-tuebingen.de

\begin{abstract}
Oncolytic virotherapy constitutes an upcoming alternative treatment option for a broad spectrum of cancer entities. However, despite great research efforts, there is still only a single US Food and Drug Administration/European Medicines Agency-approved oncolytic virus available for clinical use. One reason for that is the gap between promising preclinical data and limited clinical success. Since oncolytic viruses are biological agents, they might require more realistic in vitro tumor models than common monolayer tumor cell cultures to provide meaningful predictive preclinical evaluation results. For more realistic invitro tumor models, three-dimensional tumor cell-culture systems can be employed in preclinical virotherapy research. This review provides an overview of spheroid and hydrogel tumor cell cultures, organotypic tumor-tissue slices, organotypic raft cultures, and tumor organoids utilized in the context of oncolytic virotherapy. Furthermore, we also discuss advantages, disadvantages, techniques, and difficulties of these three-dimensional tumor cell-culture systems when applied specifically in virotherapy research. Keywords: oncolytic virotherapy, oncolytic viruses, three-dimensional cell culture, tumor modeling, preclinical testing
\end{abstract}

\section{Introduction}

The predictability of preclinical models is a crucial aspect in cancer drug development, a feature that is important not only for chemical compounds and other small molecules but also for biologics, such as virotherapeutics. Due to an inappropriate early selection of potential drug candidates (both molecular and biological), many clinical trials have led to disappointing results and thereby unnecessary costs, despite promising preclinical data. ${ }^{1}$ More reliable in vitro tumor models are required to discover more successful drug candidates, and importantly to reject ineffective drugs long before the onset of first human trials. Currently, traditional in vitro testing with two-dimensional cell cultures has limited predictability; therefore, animal trials remain the gold standard. When looking critically at all available preclinical tumor models, there still is a poor correlation with drug effectiveness found finally in clinical human trials, even when animal models are employed extensively. ${ }^{2}$ Moreover, animal models, in particular rodent models, are sometimes completely incompatible with oncolytic virotherapy research.

These general considerations apply specifically to measles-vaccine virus-based virotherapeutics, for which rodents not only do not express a suitable entry receptor but also miss the fitting cell machinery required for appropriate viral replication. As a matter of fact, oncolytic viruses (OVs), with their complex mechanisms of action, need realistic preclinical models that assure representation of such important features 
as tumor microenvironment profiles. One possible solution to this challenge is based on the employment of threedimensional cell cultures, which constitute a more valid in vitro tumor model than traditional two-dimensional monolayer cell cultures. Here, we review the most common threedimensional tumor cell-culture techniques currently used in virotherapy research. Published work in the field of oncolytic virotherapy employing tumor cell spheroids, hydrogel cultures, cultures derived from tissue specimens, organotypic raft cultures, and organoids is included and discussed in this review. In addition, we present application examples for three-dimensional cell cultures in oncolytic virotherapy. The tumor-organoid-culture model can be employed for individual patient virograms. Further, we focus on the development of novel OVs in three-dimensional cultures and the utility of three-dimensional tumor cell cultures to study viral agents targeting the extracellular matrix (ECM).

\section{Tumor cell spheroids in oncolytic virotherapy}

One of the first three-dimensional tumor cell-culture techniques employed in oncolytic virotherapy was the spheroid model. Fujiwara et al were the first to publish on the infection of spheroids with a retrovirus in $1993 .{ }^{3}$ In the following years, this three-dimensional tumor model became a frequently used approach, in addition to the common two-dimensional monolayer tumor cell culture.

\section{The spheroid tumor model}

Grown in regular culture medium on a minimally adhesive surface, tumor cells form three-dimensional aggregates and then grow to nonadhesive spheroid structures. Spheroids can mimic, especially, the physical tumor microenvironment more realistically than any other three-dimensional tumor model. With high oxygen and nutrition supply at the rim, the outer cells tend to proliferate. Because of low oxygen levels and accumulation of metabolic end products, the tumor cells in the core of the spheroid are quiescent or even necrotic in larger spheroids (up to $1 \mathrm{~mm}$ in diameter). Drug concentration and $\mathrm{pH}$ are lowered in the inner areas of the spheroid. With these zones containing cells in different metabolic states, avascular tumors can be realistically imitated (Figure 1A). Drug or viral penetration into the spheroid can be evaluated as well. For instance, Grill et al showed that nonreplicative adenoviruses infected only the outer two or three tumor cell layers, whereas replication-competent agents were able to spread through almost the whole spheroid. ${ }^{4}$ Spheroid models indicate that viral spread through all tumor areas is difficult to reach by administration on the rim of the spheroid. Therefore, among other things, OVs are often delivered by intratumoral injection in clinical virotherapy. To mimic these conditions, intraspheroidal injections could constitute a preclinical model. In this situation, OVs are challenged to replicate and spread in tumor cells exhibiting low metabolism and low proliferation.

\section{Bystander effect in three-dimensional tumor cell cultures}

Three-dimensional tumor cell interactions and contacts can also influence oncolytic activity. It has been shown that the kind and amount of tumor cell interactions like gap junctions exert a significant impact on suicide-gene-armed virotherapy
A

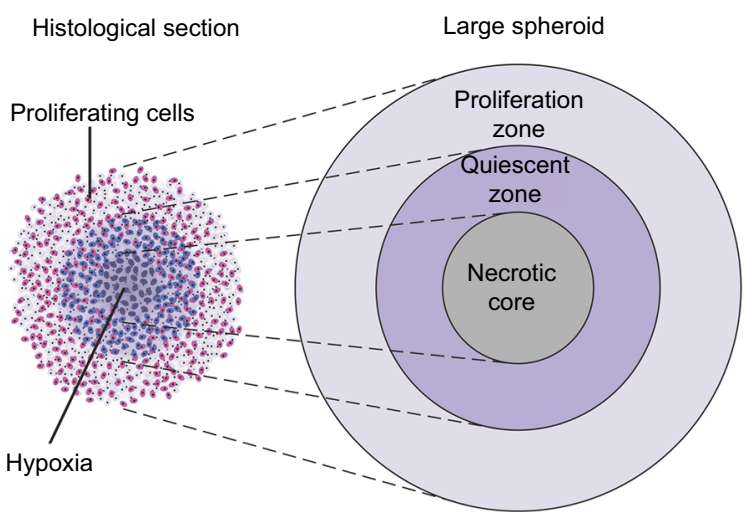

B

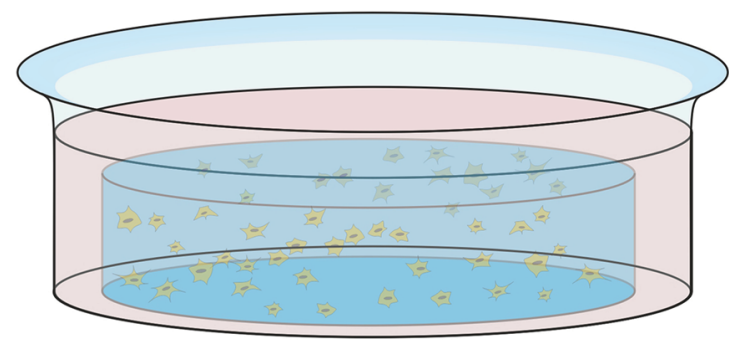

Figure I Spheroid and hydrogel culture.

Notes: (A) Depiction of a stained histological section through a large spheroid (up to I mm in diameter) makes different metabolic zones visible. Nutrition, oxygen, and drug concentrations are higher at the rim of the spheroid, whereas low $\mathrm{pH}$ and accumulation of $\mathrm{CO}_{2}$ and metabolic end products lead to necrosis in the core of the spheroid. Adapted from Verjans ET, Doijen J, Luyten W, Landuyt B, Schoofs L. Three-dimensional cell culture models for anticancer drug screening: worth the effort? J Cell Physiol. 2018;233(4):2993-3003. (C) 2017 Wiley Periodicals, Inc. ${ }^{93}$ Adapted from Lin RZ, Chang HY. Recent advances in three-dimensional multicellular spheroid culture for biomedical research. Biotechnol J. 2008;3(9-10):I I72-I 184. Copyright 2008 Wiley-VCH Verlag GmbH \& Co. KGaA. Reproduced with permission. ${ }^{94}$ (B) Depiction of a single well with a hydrogel culture. Single cells have been taken up in fluid hydrogel. When it solidifies, cells are embedded in a three-dimensional matrix that allows medium supply. 
and the so-called bystander effect. ${ }^{5}$ This refers to the spread of the activated suicide drug by diffusion into neighboring uninfected tumor cells and their subsequent nononcolytic but "genotoxic" cell death. This bystander effect can differ between two-dimensional and three-dimensional tumor cell cultures, due to different forms of tumor cell interactions, multiple tumor cell layers, and drug distribution features. ${ }^{6}$ Three-dimensional tumor cell cultures are used to study this effect more realistically. ${ }^{7}$ To sum up, three-dimensional cell cultures are especially important in the study of suicide-genearmed virotherapeutics because of the realistic representation of the bystander effect.

\section{Modifications of spheroid tumor cell model}

Additions can be made to make spheroid models more realistic and comparable to the tumor patient's native biological tumor environment. Coculture approaches have been established with tumor-associated fibroblasts, endothelial cells, or immune cells to study cell interactions. A subtype of spheroids derived from neural stem cells or brain tumor cells are called neurospheres. As they harbor several stem cell properties, neurospheres are an accepted model for studying brain tumor stem-like cells. ${ }^{8}$ Moreover, spheroids can be cultured in ECM-derived hydrogels or even directly on primary tissue slices (Table 1). ${ }^{9,10}$

Table I Virotherapy studies employing tumor cell spheroids

\begin{tabular}{|c|c|c|c|c|}
\hline $\begin{array}{l}\text { 3-D culture } \\
\text { system }\end{array}$ & $\begin{array}{l}\text { Tumor } \\
\text { entity }\end{array}$ & OV & Notes & Reference \\
\hline \multirow[t]{23}{*}{ Spheroids } & Bladder cancer & Adenovirus & Targeting cancer-initiating cells with an OV & 19 \\
\hline & $\begin{array}{l}\text { Colon } \\
\text { carcinoma }\end{array}$ & Adenovirus & $\begin{array}{l}\text { Mechanism of viral spread and penetration in epithelial } \\
\text { tissue }\end{array}$ & 25 \\
\hline & & Echovirus & Oncolytic activity in 2-D and 3-D cultures & 26 \\
\hline & & Echovirus 5 & $\begin{array}{l}\text { Using an altered infectious nucleic acid to initiate and } \\
\text { improve viral replication }\end{array}$ & 27 \\
\hline & & $\begin{array}{l}\text { Newcastle disease } \\
\text { virus }\end{array}$ & Development of more potent OVs by bioselection & 28 \\
\hline & Glioblastoma & HSVI & $\begin{array}{l}\text { Replication and oncolytic activity in animal models and } \\
\text { spheroids }\end{array}$ & 29 \\
\hline & & Reovirus & $\begin{array}{l}\text { Analysis of oncolytic activity in 2-D and 3-D } \\
\text { glioblastoma stem-like cells }\end{array}$ & 21 \\
\hline & & Reovirus & Different entry pathways in 2-D and spheroid cultures & 17 \\
\hline & & VSV & $\begin{array}{l}\text { Development and testing of a semireplication- } \\
\text { competent VSV to improve safety }\end{array}$ & 30 \\
\hline & $\begin{array}{l}\text { Glioblastoma, } \\
\text { neuroblastoma }\end{array}$ & HSVI & Degradation of ECM to enhance oncolytic activity & 31 \\
\hline & Glioma & Adenovirus & $\begin{array}{l}\text { Analysis of oncolytic activity, combinatorial virotherapy } \\
\text { with temozolomide and suicide gene }\end{array}$ & 6 \\
\hline & & Adenovirus & $\begin{array}{l}\text { Evaluation of oncolytic activity with PET and WSTI } \\
\text { assay }\end{array}$ & 24 \\
\hline & & Adenovirus & Combination of radiation and OV & 14 \\
\hline & $\begin{array}{l}\text { Glioma, breast } \\
\text { cancer }\end{array}$ & Adenovirus & $\begin{array}{l}\text { Decorin transgene to improve viral spread by } \\
\text { degrading the ECM }\end{array}$ & 32 \\
\hline & $\begin{array}{l}\text { Hepatocellular } \\
\text { carcinoma }\end{array}$ & Adenovirus & $\begin{array}{l}\text { Targeting Wnt signaling in hepatocellular carcinoma } \\
\text { stem-like cells }\end{array}$ & 20 \\
\hline & Lung cancer & Adenovirus & Targeting lung cancer stem-like cells & 18 \\
\hline & $\begin{array}{l}\text { Melanoma, } \\
\text { breast cancer }\end{array}$ & HSV2 & $\begin{array}{l}\text { Oncolytic mechanism and role of the calpain system in } \\
\text { cancer stem-like cells }\end{array}$ & 33 \\
\hline & NSCLC & $\begin{array}{l}\text { Newcastle disease } \\
\text { virus }\end{array}$ & $\begin{array}{l}\text { Oncolytic mechanism of Newcastle disease virus, } \\
\text { influence of autophagy }\end{array}$ & 34 \\
\hline & $\begin{array}{l}\text { Ovarian } \\
\text { cancer }\end{array}$ & Adenovirus & $\begin{array}{l}\text { Measurement of oncolysis in spheroids via luciferase } \\
\text { expression }\end{array}$ & 13 \\
\hline & & Adenovirus & Different efficacy in different patient samples & 35 \\
\hline & & Adenovirus & Virus replication and measurement in 3-D cultures & 12 \\
\hline & & Adenovirus & Development and preclinical testing of a novel OV & 36 \\
\hline & & Echovirus I & Preclinical testing of oncolytic potential & 37 \\
\hline
\end{tabular}


Table I (Continued)

\begin{tabular}{|c|c|c|c|c|}
\hline $\begin{array}{l}\text { 3-D culture } \\
\text { system }\end{array}$ & $\begin{array}{l}\text { Tumor } \\
\text { entity }\end{array}$ & $\begin{array}{l}\text { Oncolytic virus } \\
\text { (OV) }\end{array}$ & Notes & Reference \\
\hline & & Myxoma virus & $\begin{array}{l}\text { Different oncolytic activity in adherent and } \\
\text { nonadherent cells }\end{array}$ & 15 \\
\hline & & $\begin{array}{l}\text { Myxoma virus, } \\
\text { vaccinia virus, } \\
\text { Maraba virus }\end{array}$ & Different oncolytic activity in $2 D$ vs $3-D$ cultures & 16 \\
\hline & & Vaccinia virus & $\begin{array}{l}\text { Targeting cancer-initiating cells with chemokine- } \\
\text { receptor antagonist expressing OV }\end{array}$ & 38 \\
\hline & $\begin{array}{l}\text { Pancreatic } \\
\text { cancer }\end{array}$ & Adenovirus & $\begin{array}{l}\text { Reduction of gemcitabine resistance by degrading ECM } \\
\text { with OV }\end{array}$ & 39 \\
\hline & $\begin{array}{l}\text { Panel of tumor } \\
\text { cell lines }\end{array}$ & Adenovirus & $\begin{array}{l}\text { Degradation of ECM to increase viral distribution and } \\
\text { penetration }\end{array}$ & 40 \\
\hline & $\begin{array}{l}\text { Panel of tumor } \\
\text { cell lines }\end{array}$ & Coronavirus & $\begin{array}{l}\text { Targeting coronaviruses to EGF receptor with a } \\
\text { bispecific antibody }\end{array}$ & 41 \\
\hline & $\begin{array}{l}\text { Pediatric } \\
\text { glioma }\end{array}$ & HSVI & $\begin{array}{l}\text { Oncolytic mechanism of action, } \mathrm{OV} \text { as an anti-invasive } \\
\text { treatment }\end{array}$ & 42 \\
\hline $\begin{array}{l}\text { Spheroids, chicken } \\
\text { chorioallantoic } \\
\text { membrane models }\end{array}$ & $\begin{array}{l}\text { Pancreatic } \\
\text { cancer }\end{array}$ & Adenovirus & OV delivery using mesenchymal stromal cells & 43 \\
\hline \multirow[t]{2}{*}{$\begin{array}{l}\text { Spheroids placed } \\
\text { on brain slices }\end{array}$} & Glioma & HSVI & $\begin{array}{l}E C M \text { degradation by chondroitinase } A B C \text { enhances } \\
\text { antitumor efficacy }\end{array}$ & 10 \\
\hline & & Vaccinia virus & $\begin{array}{l}\text { Influence of microglia and astrocytes on oncolytic } \\
\text { activity }\end{array}$ & 44 \\
\hline $\begin{array}{l}\text { Spheroid } \\
\text { coculture in } \\
\text { PEG diacrylate } \\
\text { hydrogels }\end{array}$ & Glioblastoma & Adenovirus & Oncolytic potential in 3-D cocultures & 9 \\
\hline \multirow[t]{5}{*}{ Neurospheres } & Glioblastoma & Adenovirus & Targeting brain-tumor stem-like cells & 45 \\
\hline & & Adenovirus & $\begin{array}{l}\text { Targeting brain-tumor stem-like cells, role of } \\
\text { autophagy }\end{array}$ & 8 \\
\hline & & HSVI & $\begin{array}{l}\text { Sensitizing of glioblastomas to temozolomide by OV } \\
\text { expressing chondroitinase } M\end{array}$ & 46 \\
\hline & & $\begin{array}{l}\text { Measles vaccine } \\
\text { virus }\end{array}$ & Preclinical testing of OV in tumor stem-like cells & 22 \\
\hline & & Parvovirus $\mathrm{HI}$ & Oncolytic activity in glioblastoma stem-like cells & 23 \\
\hline
\end{tabular}

Abbreviations: 2-D, two-dimensional; 3-D, three-dimensional; ECM, extracellular matrix; HSV, herpes simplex virus; NSCLC, non-small-cell lung cancer; OV, oncolytic virus; PEG, polyethylene glycol; PET, positron-emission tomography; VSV, vesicular stomatitis virus.

\section{Spheroid-forming tumor cell types}

An important issue are the tumor cell lines that form the spheroids. In comparison to primary tumor cells, conventionally used tumor cell lines with high passage numbers harbor several mutations and phenotypic changes. In two-dimensional monolayer tumor cell cultures, highly proliferating tumor cells exhibiting robust adhesion to plastic cell-culture bottles and plates are selected. It has been found that both histological and genetic architecture are more conserved in three-dimensional tumor cell cultures. For example, expression of receptors and molecules that are involved in viral entry might be altered in monolayer tumor cell cultures.
To avoid the disadvantages of common tumor cell lines, some groups primarily choose purified primary tumor cells derived from vital tumor tissue of human or xenograft origin or tumor cells with very low passage numbers to form tumor cell spheroids. In this context, Bauerschmitz et $\mathrm{al}^{11}$ and Lam et $\mathrm{a}^{12}$ demonstrated adenoviral replication in spheroids derived from unpassaged purified ovarian cancer cells. Later, they showed higher primary infection rates, higher rates of subsequent replication, and viral transgene expression in monolayer tumor cell cultures, suggesting this was due to an enlarged relative surface per cell and subsequent faster initial/primary infection. ${ }^{13}$ 


\section{Therapy resistance in tumor cell spheroids}

Increased resistance to oncolysis in tumor cell spheroids displays a frequently discussed aspect. To enhance viral distribution and tumor cell killing, irradiation has been successfully combined with an oncolytic adenovirus in glioblastoma spheroids. ${ }^{14}$ Correa et al found lower myxomavirus-mediated cell killing in spheroids than in adherent cells, because of downregulated Akt kinase in nonadherent cells. ${ }^{15}$ When tumor cell spheroids are reattached to the surface, Akt is upregulated again and myxoma virus effectively kills spheroid tumor cells. Later, the same group showed a similar mechanism of tumor cell resistance in spheroids for Maraba virus and its entry molecule: the LDL (low-density lipoprotein) receptor. Reattachment of the tumor cell spheroids relieved this resistance, which can serve as a model for metastasis in this context (Table 1). ${ }^{16}$ Therefore, altered activation of cellular pathways in three-dimensional tumor cell cultures can influence viral tumor cell entry and tumor cell killing. Different entry mechanisms between two- and three-dimensional tumor cell cultures have also been studied in glioblastoma cells for reovirus. ${ }^{17}$

\section{Cancer stem-like cells in spheroids}

Tumor cells grown in low-attachment plates and serum-free medium supplemented with specific growth factors can be used to study cancer-initiating cells or cancer stem-like cells in spheroid models. Today, cancer stem-like cell-enriched spheroids can be built from nearly every type of cancer. For instance, Yang et al showed that lung cancer cells grown in spheroid cultures exhibited cancer stem-cell characteristics such that they were quiescent, drug-resistant, and only slowly proliferating. ${ }^{18}$ Similar properties were shown also for bladder cancer, liver cancer, and brain cancer cells in spheroids (Table 1). ${ }^{8,19,20}$ All these models were used to investigate adenoviral targeting on cancer stem-like cells. Resistant cancer stem-like cells constitute a major hurdle in cancer therapy, especially when combating glioblastomas. As such, reovirus, measles vaccine virus, and parvovirus have been successfully targeted to glioblastoma stem-like cells in spheroid models. ${ }^{21-23}$ In future, standard chemotherapy regimens could be augmented with cancer stem-like cell-killing OVs to eradicate all tumor cell populations in an additive immunovirotherapeutic approach.

\section{Quantification of oncolysis}

Unsolved problems are the heterogeneous size of the spheroids and the measurement of tumor cell-mass reduction and viral oncolysis without disintegration of the spheroids. Idema et al investigated different approaches to quantify viral oncolysis in this model. ${ }^{24}$ They recommend fluorodeoxyglucose positron-emission tomography as an option for sequential measurement of the same spheroids. Of note, this is a nondestructive but elaborate approach, quite useful to avoid disintegration of the spheroids for single measurements. When applied to very simple measurements, such as a mere determination of volume alterations of spheroids, such approaches cannot be considered suitable in providing valid parameters for quantification of oncolysis (in the course of virus replication, tumor cell volumes can be altered, despite the fact that oncolysis has not yet started).

\section{Conclusion}

The spheroid model should be favored to mimic the physical tumor environment and tumor cells in different metabolic situations and cell cycle states (Table 2).

Table 2 Summary of advantages and disadvantages of the five cell-culture systems

\begin{tabular}{lll}
\hline Cell-culture system & Advantages & Disadvantages \\
\hline Spheroids & Different metabolic zones and physical gradients & $\begin{array}{c}\text { Only one cell type contained and hence } \\
\text { provides an inadequate representation } \\
\text { of the tumor microenvironment } \\
\text { Hydrogel composition may influence } \\
\text { Hydrogel cultures }\end{array}$ \\
& $\begin{array}{l}\text { Cell-virus ECM interactions can be studied; coculture with } \\
\text { fibroblasts or even endothelial cells is easy }\end{array}$ & cells and differs from real tumor ECM; \\
lower cell density than normal tissue & Differences between the specimens; & only culturable for a few days \\
cultures & cells, as well as tumor endothelium & Only suitable for epithelial tissues \\
Organotypic raft cultures & Resemble epithelial architecture and differentiation & Expensive culture materials; niche and \\
Organoids & Contain stem cells and differentiated cells; relatively easy to & growth factors might change tumor \\
& maintain; can be shared and expanded; maintain genetic tumor & behavior
\end{tabular}

Abbreviation: ECM, extracellular matrix. 


\section{Culture systems utilizing hydrogels in oncolytic virotherapy}

The ECM plays a major role in tumor growth, behavior, and therapy resistance. To mimic this biological aspect in preclinical tumor models, advanced culture systems are required. For this purpose, natural or synthetic hydrogels can be employed.

\section{Materials for hydrogel culture}

Most commonly used for ECM containing cell cultures is Matrigel, a laminin-rich and ECM-derived hydrogel. Matrigel is just one trade name for this product; similar ECM-derived hydrogels are available under different names. Matrigel includes several ECM proteins and is produced by the murine sarcoma cell line EHS. As it is fluid at $4^{\circ} \mathrm{C}$ and solidifies through protein polymerization at $37^{\circ} \mathrm{C}$, Matrigel can be used in cell cultures easily. Further approaches use collagenderived matrices or synthetically engineered polyethylene glycol (PEG)-based hydrogels (Table 3). ${ }^{9,47,48}$ Collagen is a well-known structural protein of the connective tissue, and can be selectively lysed by collagenase in cell culture to release cells from the collagen matrix. Hydrogels provide a three-dimensional scaffold that encapsulates the cells and makes nutrient exchange possible (Figure 1B). Under these culture conditions, cells maintain their biological phenotype.

\section{Matrigel usage in oncolytic virotherapy}

Matrigel-derived three-dimensional tumor cell cultures were first investigated in drug testing, and constitute a relatively new approach in oncolytic virotherapy. Because of the large scale of viral agents compared to molecular drugs, Matrigel has a great influence on viral distribution and spread. Viral binding to different ECM proteins also contributes to inhibition of viral spread. ${ }^{49}$ Valyi-Nagy et al studied Matrigel cell cultures extensively using uveal melanoma cell lines..$^{50}$ Later, the same group extended the experiments with breast, prostate, and embryonic cancer cells. ${ }^{51}$ In this work, they found differences in growth patterns among the varying cells in three-dimensional cell cultures and obvious differences in common two-dimensional cell cultures. With herpes simplex virus 1 (HSV1), their results indicated massive inhibition of viral penetration through Matrigel. Furthermore, they infected cells in a monolayer tumor cell culture and embedded them in the Matrigel matrix after infection. Comparing this model with a two-dimensional cell culture, they demonstrated ECM-mediated inhibition of viral replication after viral entry. This "quiescent" infection was relieved by the outgrowth of single cells from cell aggregates in a three-dimensional culture. Then, single "outgrown" tumor cells started again to express virus-encoded GFP as a marker for viral replication. In summary, at least two mechanisms of resistance in Matrigel cell cultures were found: on one hand, the physical Matrigel barrier working quite efficiently against viral distribution and spread, and on the other, the ECM-mediated suppression of viral replication (Table 3)..$^{50,51}$

\section{Collagen gels in oncolytic virotherapy}

A collagen gel model has been used to study stroma-selective targeting via human or murine urokinase receptors in a coculture of murine fibroblasts with human breast cancer cells, which led to a significant increase in tumor cell growth. Selective infection of the murine fibroblasts with an oncolytic measles vaccine virus decreased tumor cell proliferation in this coculture model. Supported by a mouse model, the authors concluded that stroma-selective targeting per se constituted an efficient treatment option, even though

Table 3 Virotherapy studies using hydrogel culture models

\begin{tabular}{|c|c|c|c|c|}
\hline 3-D culture system & Tumor entity & ov & Notes & Reference \\
\hline Collagen-gel coculture model & Breast cancer & Measles vaccine virus & Targeting tumor stroma with OV & 47 \\
\hline \multirow[t]{4}{*}{ Matrigel cultures } & Epithelial ovarian cancer & Adenovirus & $\begin{array}{l}\text { Development of OVs using } \\
\text { directed evolution in 2-D vs 3-D } \\
\text { cultures }\end{array}$ & 53 \\
\hline & $\begin{array}{l}\text { Prostate adenocarcinoma, } \\
\text { breast adenocarcinoma, } \\
\text { embryonic teratocarcinoma }\end{array}$ & HSVI & $\begin{array}{l}\text { Oncolytic activity in 2-D vs 3-D } \\
\text { cultures; impact of ECM on } \\
\text { resistance }\end{array}$ & 51 \\
\hline & Prostate cancer & Adenovirus & $\begin{array}{l}\text { Targeting tumor and tumor } \\
\text { endothelium }\end{array}$ & 52 \\
\hline & Uveal melanoma & HSVI & $\begin{array}{l}\text { Identification of resistant tumor } \\
\text { cell populations; impact of ECM }\end{array}$ & 50 \\
\hline PEG-fibrin hydrogel & Lung adenocarcinoma & Adenovirus & $\begin{array}{l}\text { Oncolytic activity in 3-D cultures, } \\
\text { role of stromal components and } \\
\text { microenvironment }\end{array}$ & 48 \\
\hline
\end{tabular}

Abbreviations: 2-D, two-dimensional; 3-D, three-dimensional; ECM, extracellular matrix; HSV, herpes simplex virus; OV, oncolytic virus. 
targeting both tumor and tumor stroma led to the strongest antitumor effect. ${ }^{47}$

\section{Coculture approaches}

Jin et al employed a Matrigel coculture of human umbilical vein endothelial cells (HUVECs) and prostate cancer cells to examine the interactions between them. ${ }^{52}$ They proved an angiogenic effect of prostate cancer cells on HUVEC tubular formation in three-dimensional cultures. Infection of prostate cancer cells with an oncolytic adenovirus reduced the vasculogenic network in this model. To sum up, the authors recommended a combinatorial therapy with adenovirus targeting cancer cells and a second adenovirus targeting the VEGF pathway in prostate cancer. Combination of different three-dimensional culture techniques has led to more useful and realistic tumor models for preclinical evaluation of OVs. Avci et al grew spheroids from cocultured glioma cells and endothelial cells in microwells of a synthetic PEG diacrylate hydrogel to evaluate the efficacy of an oncolytic adenovirus. ${ }^{9}$ Interestingly, the reduction in cell viability in this model was larger than in a monolayer coculture of the same cells. Perhaps susceptibility to the adenovirus was increased in the three-dimensional model because there was no hydrogel matrix between the cells, as they were grown in PEG diacrylate hydrogel microwells.

\section{Conclusion}

Hydrogel models are optimal when facing the ECM aspect of the tumor microenvironment (Table 2).

\section{Employing organotypic tissue cultures in virotherapy}

The most logical way to come to a preclinical tumor model that is closest to original in vivo tumor biology is to employ resected tumor tissue itself. For organotypic tumor-tissue slices, resected tumor samples are cut thinly (in general, about $300 \mu \mathrm{m}$ thick) and then cultured in media for a few days (Figure 2A). Beyond that, it is also possible to culture and infect whole tissue fragments as well. The advantages of these techniques are obvious: composition of the ECM, as well as composition and architecture of the different cell

A Cut on a microslicer

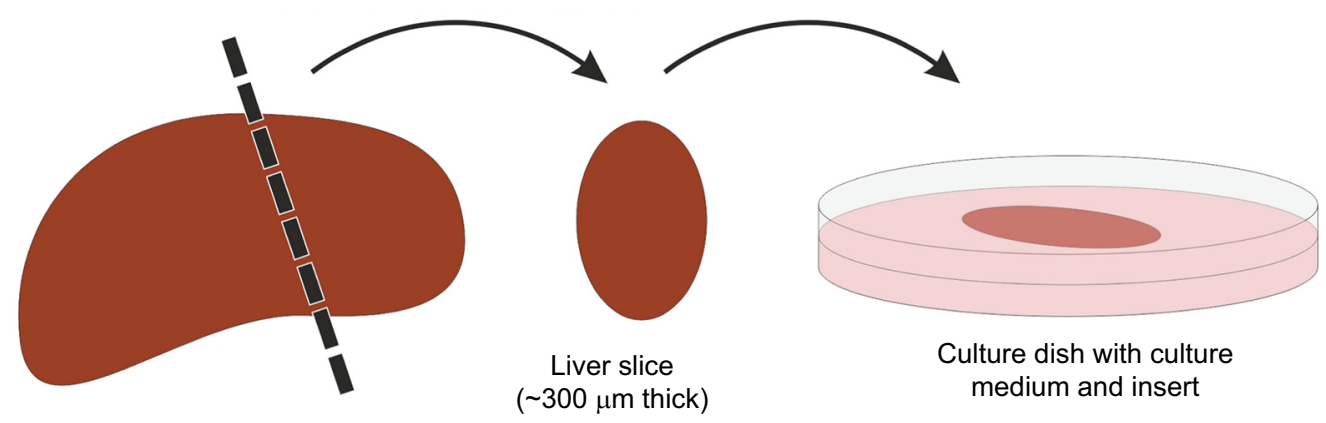

Mouse liver

B

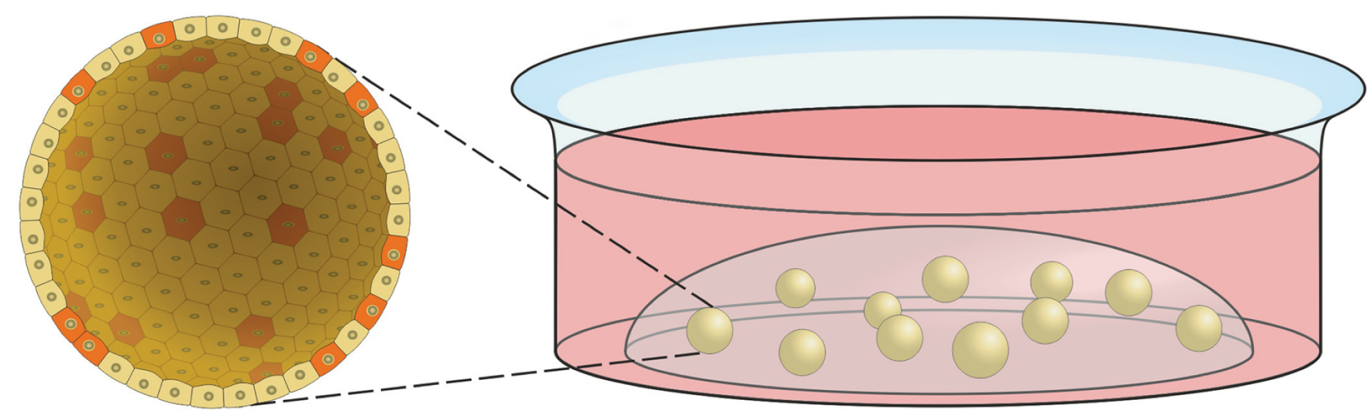

Figure 2 Organotypic tissue slices and organoids.

Notes: (A) Preparation of an organotypic tissue slice. After cutting, slices can be cultured in cell-culture media for several days. Special inserts in culture dishes ensure that the slices are close to the surface of the culture medium for a sufficient oxygen supply. (B) Organoid culture, stem cells provided with stem cell, and niche factors form organoids in a three-dimensional matrix (in general hydrogel). A section through a spherical organoid (up to $500 \mu \mathrm{m}$ in diameter) is enlarged so that single cells become visible. Stem-like cells are shown in red and differentiated cells in yellow. Cells in organoids form a flat structured surface outward. Internally, they build a lumen in which dead cells accumulate after some time. 
types, remain the same. Organotypic slices harbor tumorassociated fibroblasts, tumor endothelium, and even immune cells, which constitute a key point in tumor development and behavior. With its endogenous immune cells, organotypic tissue has been shown to be able to generate an inflammatory environment and even an antiviral response itself. ${ }^{54}$ This makes it suitable for investigating interactions of OVs with tumor-associated immune cells. Despite these benefits, this approach has become less popular within the last few years. One problem is modest reproducibility, as every tumor-tissue slice has individual composition, cell count, and viability. This can also be influenced by the surgical resection procedure or pretreatment of the tumor. Therefore, comparisons and quantifications are quite difficult in this model. Besides this, organotypic slices cannot be shared or passaged and can only be cultured for a short period, resulting in a low number of samples being available (Table 2). Of note, the importance of this culture system for gene therapy and virotherapy was reviewed by Jakeman et al recently. ${ }^{55}$

\section{Organotypic slices as a safety assay}

One favorable aspect of the organotypic slice culture is that tumor borders can be cut in slices, and as such, it is possible to culture healthy tissue next to tumor tissue in a single slice. This is particularly important for safety studies in virotherapy, as infection with OVs should be restricted primarily to tumor cells. In this context, the organotypic slice model has been used several times to assess the safety profile and specificity of viral agents (Table 4). ${ }^{56-63}$ Rots et al investigated the tumor-on/liver-off profile of replicating adenoviruses with tissue slices prepared from tumor tissue and others from liver tissue. ${ }^{57}$ Viral replication was demonstrated via transgene expression of GFP or luciferase. Moreover, they quantified viral DNA in the supernatant. In conclusion, the authors showed replication of the wild-type adenovirus in liver slices, whereas replication of the tumor-targeted virus was almost fully restricted to tumor slices and attenuated in liver slices. Mixed slices containing tumor and healthy liver tissue were employed by Zimmermann et al. ${ }^{56}$ They studied oncolytic

Table 4 Virotherapy studies employing organotypic tissue cultures

\begin{tabular}{|c|c|c|c|c|}
\hline 3-D culture system & Tumor entity & OV & Notes & Reference \\
\hline \multirow[t]{12}{*}{ Organotypic slices } & Breast cancer & Adenovirus & $\begin{array}{l}\text { Tumor specificity using mRNA } \\
\text { translational control }\end{array}$ & 58 \\
\hline & & & Replication and infectivity in 3-D cultures & 66 \\
\hline & & & $\begin{array}{l}\text { Comparison of efficacy of different } \\
\text { adenoviruses }\end{array}$ & 67 \\
\hline & & & $\begin{array}{l}\text { Tissue-specific promoters to provide } \\
\text { tumor specificity }\end{array}$ & 59 \\
\hline & Colon carcinoma & Adenovirus & $\begin{array}{l}\text { Precision-cut tumor-tissue slices for } \\
\text { preclinical evaluation }\end{array}$ & 57 \\
\hline & Glioma & Adenovirus & $\begin{array}{l}\text { Developing and testing of a TRAIL-armed } \\
\text { OV }\end{array}$ & 68 \\
\hline & & HSVI & $\begin{array}{l}\text { Impact of macrophage and microglia } \\
\text { depletion on intratumoral virus titers }\end{array}$ & 69 \\
\hline & & Vesicular stomatitis virus & $\begin{array}{l}\text { Oncolytic activity and toxicity of vesicular } \\
\text { stomatitis virus }\end{array}$ & 70 \\
\hline & Liver slices & Adenovirus & Hepatotoxicity of oncolytic adenovirus & 60 \\
\hline & Melanoma & Newcastle disease virus & $\begin{array}{l}\text { Influence of ECM on virus spread and } \\
\text { oncolysis }\end{array}$ & 71 \\
\hline & $\begin{array}{l}\text { Primary and } \\
\text { secondary liver } \\
\text { tumors }\end{array}$ & Measles vaccine virus & $\begin{array}{l}\text { Precision-cut liver tumor slices for } \\
\text { preclinical evaluation of oncolytic measles } \\
\text { vaccine virus }\end{array}$ & 56 \\
\hline & $\begin{array}{l}\text { Prostate cancer, } \\
\text { brain tumors }\end{array}$ & HSVI & $\begin{array}{l}\text { Protocol for testing HSVI in organotypic } \\
\text { cultures }\end{array}$ & 72 \\
\hline \multirow[t]{4}{*}{ Tissue explants } & Bladder cancer & Vaccinia virus & $\begin{array}{l}\text { Preclinical testing of selectivity and safety } \\
\text { of vaccinia virus }\end{array}$ & 64 \\
\hline & $\begin{array}{l}\text { Colorectal cancer, } \\
\text { cervical cancer }\end{array}$ & Vaccinia virus & $\begin{array}{l}\text { Clinical trial for intravenous application of } \\
\text { a vaccinia virus targeting the Ras pathway }\end{array}$ & 65 \\
\hline & Prostate cancer & HSVI & $\begin{array}{l}\text { Analysis of oncolytic activity and } \\
\text { mechanism }\end{array}$ & 61 \\
\hline & & & $\begin{array}{l}\text { Combining vinblastine and } \mathrm{OV} \text { to target } \\
\text { tumor and neovasculature }\end{array}$ & 62 \\
\hline
\end{tabular}


activity of different measles vaccine virus strains in organotypic slices and showed a tumor favoring an infection profile, being demonstrated by higher levels of GFP-marker gene expression, as well as viral protein detection in tumor areas. In summary, they recommended the precision-cut slice model for individual patient selection of the most effective OV.

\section{Tissue explants}

Tissue explants are small fragments of tumor tissue obtained from surgery and cultured in media for several days. Unlike the slice model, they are not cut into defined pieces. Upon infection, it is possible to observe viral transgene expression to prove viral replication in tumor tissue. Moreover, tissue explants from healthy tissue can be utilized to check tumor selectivity (Table 4). ${ }^{64,65}$

\section{Evaluation of cell specificity with tissue specimens}

Cutting and immunostaining tissue fragments after in vitro infections can demonstrate viral cell specificity in a realistic three-dimensional tumor environment. Passer et al stained prostate tissue samples after infecting them with an oncolytic $\mathrm{HSV}^{61}$ Thereby, they showed that replication of a genetically engineered HSV was restricted to epithelial cells, whereas the parental (wild-type) HSV vector also infected stromal components. Later, they used this model again to provide evidence that replication of an IL2-armed oncolytic HSV only takes place in epithelial prostate cancer cells (Table 4) ${ }^{62}$

\section{Conclusion}

Organotypic tissue cultures are the closest model to the in vivo tumor situation, retaining the original three-dimensional tumor architecture and cell composition. Since they cannot be maintained in vitro for long periods, close clinical cooperation with respective surgical departments is required.

\section{Organotypic raft cultures}

The organotypic raft culture (using metal raft grids) became popular in virology to study pathogenesis of human papilloma virus. For epithelial tissue, this model realistically resembles the differentiation of keratinocytes. ${ }^{73}$ Primary keratinocytes or keratinocytes with low passages are seeded on top of a hydrogel matrix (in general, collagen gel). That induces differentiation of keratinocytes and finally becomes close to the histological architecture of epithelial tissues like the skin or the cervix (Table 5).

\section{Conclusion}

Organotypic raft cultures are the model of choice to mimic epithelial differentiation and epithelial cancers (Table 2).

\section{Chicken chorioallantoic membrane model}

A special model to grow solid tumors with vasculature is the chicken chorioallantoic membrane (CAM) model. Immortalized tumor cells can be seeded on the chorioallantoic membrane of prepared chicken eggs. After seeding, tumor cells are incubated for up to 2 weeks in eggs to grow to small solid tumors. As the chorioallantoic membrane is highly vascularized, neovessels from the chicken egg grow into tumors. During this period, the tumors can be infected with OVs. Then, tumors are fixed and stained. It was found that CAM tumors were well organized and histologically resembled clinical tumor-tissue samples (Table 5). ${ }^{74}$

\section{Organoids and tumoroids as suitable models for oncolytic virotherapy}

In the past few years, organoids have become an increasingly investigated three-dimensional preclinical model. The

Table 5 Virotherapy studies using organotypic raft cultures, the CAM model, or organoid culture

\begin{tabular}{|c|c|c|c|c|}
\hline 3-D culture system & Tumor entity & $\begin{array}{l}\text { Oncolytic } \\
\text { virus }\end{array}$ & Notes & Reference \\
\hline CAM & $\begin{array}{l}\text { Melanoma, colorectal } \\
\text { carcinoma, glioblastoma }\end{array}$ & Adenovirus & $\begin{array}{l}\text { CAM tumor assay for preclinical testing of } \\
\text { adenoviruses }\end{array}$ & 74 \\
\hline Organotypic raft & Cervical cancer & Adenovirus & Safety and efficacy of oncolytic adenoviruses & 75 \\
\hline \multirow[t]{3}{*}{ cultures } & Cervical cancer & Adenovirus & $\begin{array}{l}\text { Organotypic keratinocyte culture for } \\
\text { preclinical testing of oncolytic adenoviruses }\end{array}$ & 76 \\
\hline & $\begin{array}{l}\text { Head-and-neck squamous- } \\
\text { cell carcinomas }\end{array}$ & Adenovirus & $\begin{array}{l}\text { Targeting adenoviruses to surface antigens } \\
\text { with antibodies }\end{array}$ & 77 \\
\hline & Melanoma & Adenovirus & Different cell selectivity in $2-D$ vs $3-D$ cultures & 78 \\
\hline Organoids & Glioblastoma & Zika virus & $\begin{array}{l}\text { Oncolytic activity and specificity to } \\
\text { glioblastoma stem-like cells }\end{array}$ & 63 \\
\hline
\end{tabular}

Abbreviations: 2-D, two-dimensional; 3-D, three-dimensional; CAM, chicken chorioallantoic membrane. 
fundamental idea of the organoid culture is the cultivation of stem cells that differentiate to the varying cell types of the mimicked tissue. This can be achieved by two basic techniques: stem cells are maintained in serum-free media supplemented with several tissue-specific growth and niche factors, and stem cells are embedded in a three-dimensional matrix, in general Matrigel (Figure 2B). When choosing the right medium supplements, organoid formation will be successful. As many tissue types contain adult stem cells, organoid cultures can be established from primary tissue specimens that are enzymatically digested and mechanically crushed into single cells. This new method was introduced by Sato et al in $2009 .{ }^{79}$ They cultured murine intestinal crypts from isolated intestinal stem cells or crypts in an organoid culture with Matrigel. Since then, organoids have been built from many healthy murine and human tissue types. Today, there is widespread success, especially with murine organoids, as they grow more quickly and are easier to maintain. Since protocols and recipes for growth media in human-organoid cultures are relatively new, they might require further optimization.

\section{Tumoroids}

A further step in the development of organoid cultures are socalled tumoroids. This type of organoid culture is derived from tumor specimens and maintained like any common nonmalignant organoid culture. Until now, human tumoroids have been established successfully from colon cancer, ${ }^{80,81}$ prostate $^{82}$ and pancreatic tumors, ${ }^{83}$ primary liver cancer, ${ }^{84}$ and glioblastoma.${ }^{85}$ Whether all tumoroids harbor stem-cell features remains unclear. However, it has been shown that they keep not only driver mutations but also their individual mutation patterns, even after long culture periods. Recently, a strong correlation between clinical treatment response and predictions of patientderived organoids was reported for metastatic gastrointestinal cancers. ${ }^{86}$ This work was applied to targeted therapy, but the results might also be valid for virotherapy.

\section{Advantages and disadvantages}

The major benefit of the organoid culture is that it is easy to handle when compared to other three-dimensional culture systems. Organoids can be cryopreserved, shared, passaged, and expanded over long periods. Moreover, there are standardized protocols for maintaining organoid cultures. This makes them suitable for large-scale drug screening, including usage of biological agents, such as OVs. Moreover, current approaches use organoid cocultures with fibroblasts to mimic stromal components of the tumor microenvironment. ${ }^{87}$
Immune cells can also be integrated in the organoid-culture model by maintaining them in surrounding Matrigel medium. Matrigel infiltration of $\mathrm{T}$ lymphocytes has been observed recently. ${ }^{88}$

Disadvantages are high costs of culture materials and the lack of tumor endothelium. Moreover, the growth- and niche-factor-supplemented medium might influence tumor behavior. As in hydrogel cultures, large viral agents might be influenced in their spreading capabilities by Matrigel in its solid constitution. To overcome this limitation, organoids can be cultured in Matrigel suspensions or even without a hydrogel matrix (Table 2).

\section{Organoids in virotherapy}

To our knowledge, there has only been one published work on organoids in the field of oncolytic virotherapy. Since the pathogenesis of Zika virus was extensively studied in brain organoids during the outbreak in Brazil in 2015 and 2016, Zhu et al transferred this model to the field of oncolytic virotherapy (Table 5). ${ }^{63}$ They proved the oncolytic efficacy of Zika virus in glioblastoma stem-like cells. Unlike other Flaviviridae, Zika virus replicates selectively in cancer stemlike cells and does not infect differentiated glioblastoma cells. Therefore, the authors measured organoid areas and made immunofluorescent stains of proliferation, stem cell, and apoptosis markers. They also used organotypic slices to assess the safety of Zika virus as an oncolytic agent. In summary, the authors concluded that Zika virus held effective oncolytic potential against glioblastoma, but further studies and genetic engineering have to be done to achieve safe and efficient antitumoral treatment in the future.

\section{Conclusion}

Organoids are easy to maintain and passage, and hence represent a useful alternative to the common monolayer cell cultures. They were shown to resemble in vivo tumor situations realistically, but high costs have to be taken into account.

\section{Individual patient "virograms" for guided treatment in virotherapy}

To apply the benefits of individual drug screening with organoids to virotherapy, we suggest individual patient "virograms" (Figure 3). Tumor-tissue specimens from biopsies or tumor resections could be used to culture tumor-derived organoids. Tumoroids provide a realistic personal tumor model that is easy to maintain and holds individual histological and genetic patterns. For future studies, even coculture systems 

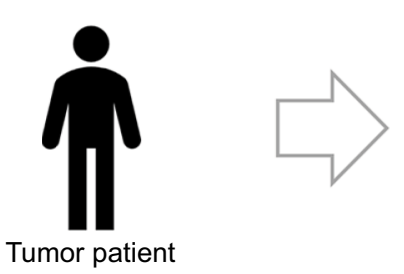

Tumor patient

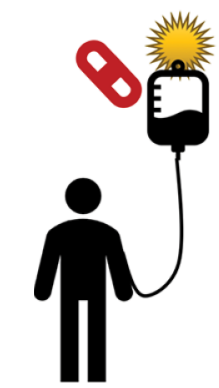

"Virogram" guided treatment with OV and combinatorial anticancer agents

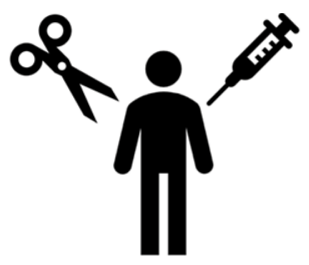

Surgical tumor resection or biospy
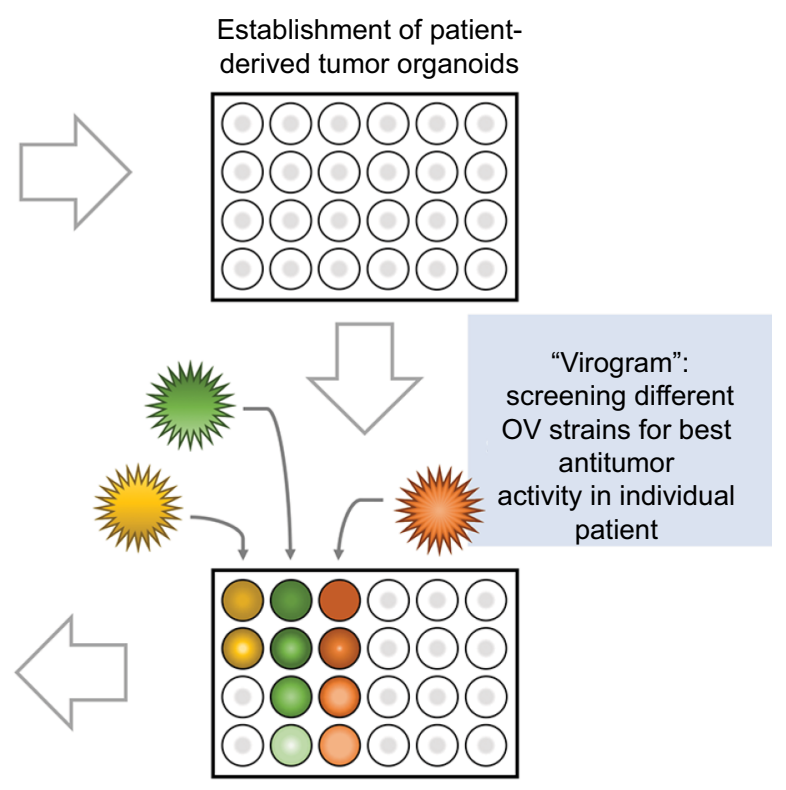

Figure 3 Individual patient virogram employing patient-derived tumor organoids. Abbreviation: OV, oncolytic virus.

with patient-derived lymphocytes or fibroblasts are conceivable. After expanding the culture, different OV strains and species (as well as other antitumoral compounds) could be tested in an individual patient virogram. Then, the viral agent with the best oncolytic efficacy could be picked for the patient's treatment. Such patient-guided virotherapy could be combined with other modalities of cancer therapies, eg, immune-checkpoint inhibition, which seems to be an ideal complementary treatment option. ${ }^{89}$

\section{Development of OVs in three- dimensional cultures}

Another innovative application focuses on the development of novel OVs. Without any direct genetic engineering, OVs are generated by bioselection in tumor cell cultures. In accordance with this, Kuhn et al established a "directed evolution" method in a three-dimensional Matrigel culture of ovarian cancer cells. ${ }^{53}$ In a first step, several serotypes of adenoviruses were mixed and mutagenesis induced chemically. Afterward, this viral pool was used to infect ovarian cancer cells with high multiplicities of infection to allow recombination among the different viral serotypes. Then, tumor cell cultures were infected with low multiplicities of infection and the viral pool obtained from this supernatant used for a next/subsequent infection cycle. Several passages of the viral pool led to the selection of the most potent and effective viral isolates. Kuhn et al employed two- and three-dimensional cultures of ovarian cancer cells for this approach and compared the resultant viral isolates. In vitro, the viral isolate from the two-dimensional cell culture was as efficient as the virus derived from the three-dimensional culture. However, in a mouse model of intraperitoneal carcinomatosis of ovarian cancer, the virus developed in three-dimensional cell culture was found to be more effective than an OV derived from two-dimensional cell culture. Moreover, this virus showed greater tumor selectivity, due to its attenuation in normal human cells. The authors concluded that Matrigel cultures might be superior for bioselection of OVs, as they are much closer to in vivo tumor biology than any other cultures.

\section{Arming oncolytic agents with ECM- degrading transgenes}

Three-dimensional tumor cell cultures are the favorable tumor model to study interactions between OVs and the ECM. A dense ECM seems to be a barrier to chemotherapeutic treatment and is associated with chemoresistance, particularly in glioblastoma and pancreatic cancer. It has even been shown that desmoplasia (proliferation of fibrous and connective tissue) can accelerate tumor progression. ${ }^{90}$ Viral spread and penetration in glioblastomas are also reduced by the ECM. Yaacov et al proved that the ECM limits viral spread and thus viral replication in a tissue-slice model. ${ }^{71}$ They studied the oncolytic efficacy of Newcastle disease virus with murine melanoma and human lung cancer tissue slices. Of note, 
pretreatment with ECM-degrading enzymes (collagenase and heparinase) enhanced viral distribution and progeny in these culture models.

\section{Employing a chondroitinase transgene}

Degradation of chondroitin sulfates by using chondroitinase $\mathrm{M}$ (ChaseM) enzyme as a transgene in an oncolytic HSV vector reduces cell aggregation and formation of neurospheres, which is an indicator of antitumor efficacy. Further, degradation of the ECM by Chase M increases viral dissemination and oncolytic tumor cell killing. Moreover, it relieves chemoresistance to temozolomide in glioblastoma. ${ }^{46}$ Safety and effectiveness of HSV vectors encoding a Chase transgene had been studied earlier by culturing glioblastoma spheroids on brain-tissue slices. ${ }^{10}$ Chase expression did not enhance glioma-cell invasiveness in this model, but positively affected viral spread and thereby viral efficacy.

\section{Insertion of a relaxin transgene}

Another transgene to break down the ECM is the peptide hormone, which inhibits production of extracellular collagen and enhances collagenase expression. A relaxin-expressing adenovirus was shown to spread into the core of cancer spheroids, whereas an unarmed control virus was only able to infect outer cell layers. ${ }^{40}$ Besides improved viral spread and replication, relaxin reduces ECM components in pancreatic cancer spheroids and restores their sensitivity to gemcitabine (Table 1). ${ }^{39}$ Furthermore, it has been shown that relaxin improves the efficacy of antibody therapy as well. This finding could be important for combinatorial treatment applying OVs together with immune-checkpoint inhibitors. ${ }^{91}$

\section{Further ECM-targeting approaches}

Other possibilities of overcoming the ECM barrier are the insertion of a matrix metalloproteinase enzyme that degrades collagen ${ }^{31,92}$ or arming OVs with a decorin transgene (Table 1). ${ }^{32}$ Like relaxin, decorin has been shown to suppress collagen synthesis and interact with other ECM proteins.

\section{Conclusion}

Until now, three-dimensional tumor cell cultures have been used as an additional method to confirm or deny results from different preclinical tumor models, such as traditional monolayer cell cultures or animal models. Their more realistic depiction of the in vivo tumor environment helps us to understand and improve therapy options for cancer patients, such as oncolytic virotherapy. This is particularly important for OVs, because their oncolytic efficiency depends on cell metabolism, activity of signaling pathways, expression of entry receptors, and their spreading capabilities being strongly influenced by the ECM, tumor stroma, and the immune system. To investigate this complex mechanism of action, more complex in vitro tumor models are required. In this regard, each model has favorable aspects. Tumor cell spheroids are able to mimic tumor cells in different metabolic states and provide realistic chemical gradients. To study the interaction of OVs with the ECM, hydrogel culture systems seem to be the best solution. Organotypic tissue cultures derived from primary tumor tissue maintain the histological cell architecture of the tumor, and can be employed as safety assays for OVs as well. For epithelial cancers, organotypic raft cultures can constitute a suitable in vitro model. Tumor-organoid cultures are easiest to handle, and can mimic stem-cell properties and virus-ECM interactions. Of course, further investigations have to be done to establish three-dimensional cell cultures as a common alternative to more traditional assays. However, such research efforts are expected to be fruitful and most probably will open up new opportunities in the field of oncolytic virotherapy.

\section{Acknowledgments}

We are grateful to Hannes Schramm for his support with the figures. We further acknowledge support from the Deutsche Forschungsgemeinschaft and the Open Access Publishing Fund of the University of Tübingen.

\section{Disclosure}

LDK is funded by the intramural Interdisziplinäres Zentrum für Klinische Forschung [Interdisciplinary Center for Clinical Research] scholarship of the Faculty of Medicine, University of Tübingen. The authors report no other conflicts of interest in this work.

\section{References}

1. McKim JM Jr. Building a tiered approach to in vitro predictive toxicity screening: a focus on assays with in vivo relevance. Comb Chem High Throughput Screen. 2010;13(2):188-206.

2. Mak IW, Evaniew N, Ghert M. Lost in translation: animal models and clinical trials in cancer treatment. Am J Transl Res. 2014;6(2):114-118.

3. Fujiwara T, Grimm EA, Mukhopadhyay T, Cai DW, Owen-Schaub LB, Roth JA. A retroviral wild-type p53 expression vector penetrates human lung cancer spheroids and inhibits growth by inducing apoptosis. Cancer Res. 1993;53(18):4129-4133.

4. Grill J, Lamfers ML, van Beusechem VW, et al. The organotypic multicellular spheroid is a relevant three-dimensional model to study adenovirus replication and penetration in human tumors in vitro. $\mathrm{Mol}$ Ther. 2002;6(5):609-614.

5. Finocchiaro LM, Bumaschny VF, Karara AL, Fiszman GL, Casais CC, Glikin GC. Herpes simplex virus thymidine kinase/ganciclovir system in multicellular tumor spheroids. Cancer Gene Ther. 2004;11(5): $333-345$. 
6. Kostova Y, Mantwill K, Holm PS, Anton M. An armed, YB-1-dependent oncolytic adenovirus as a candidate for a combinatorial anti-glioma approach of virotherapy, suicide gene therapy and chemotherapeutic treatment. Cancer Gene Ther. 2015;22(1):30-43.

7. Singleton DC, Li D, Bai SY, et al. The nitroreductase prodrug SN 28343 enhances the potency of systemically administered armed oncolytic adenovirus ONYX-411NTR. Cancer Gene Ther. 2007;14(12):953-967.

8. Jiang H, Gomez-Manzano C, Aoki H, et al. Examination of the therapeutic potential of Delta-24-RGD in brain tumor stem cells: role of autophagic cell death. J Natl Cancer Inst. 2007;99(18):1410-1414.

9. Avci NG, Fan Y, Dragomir A, et al. Delta-24-RGD induces cytotoxicity of glioblastoma spheroids in three dimensional PEG microwells. IEEE Trans Nanobioscience. 2015;14(8):946-951.

10. Dmitrieva N, Yu L, Viapiano M, et al. Chondroitinase ABC I-mediated enhancement of oncolytic virus spread and antitumor efficacy. Clin Cancer Res. 2011;17(6):1362-1372.

11. Bauerschmitz GJ, Lam JT, Kanerva A, et al. Treatment of ovarian cancer with a tropism modified oncolytic adenovirus. Cancer Res. 2002;62(5):1266-1270.

12. Lam JT, Bauerschmitz GJ, Kanerva A, et al. Replication of an integrin targeted conditionally replicating adenovirus on primary ovarian cancer spheroids. Cancer Gene Ther. 2003;10(5):377-387.

13. Lam JT, Hemminki A, Kanerva A, et al. A three-dimensional assay for measurement of viral-induced oncolysis. Cancer Gene Ther. 2007;14(4):421-430.

14. Lamfers ML, Idema S, Bosscher L, et al. Differential effects of combined Ad5-24RGD and radiation therapy in in vitro versus in vivo models of malignant glioma. Clin Cancer Res. 2007;13(24):7451-7458.

15. Correa RJ, Komar M, Tong JG, et al. Myxoma virus-mediated oncolysis of ascites-derived human ovarian cancer cells and spheroids is impacted by differential Akt activity. Gynecol Oncol. 2012;125(2):441-450.

16. Tong JG, Valdes YR, Barrett JW, et al. Evidence for differential viral oncolytic efficacy in an in vitro model of epithelial ovarian cancer metastasis. Mol Ther Oncolytics. 2015;2:15013.

17. Dautzenberg IJC, van den Wollenberg DJM, van den Hengel SK, et al. Mammalian orthoreovirus T3D infects U-118 MG cell spheroids independent of junction adhesion molecule-A. Gene Ther. 2014;21(6):609-617.

18. Yang Y, Xu H, Huang W, et al. Targeting lung cancer stem-like cells with TRAIL gene armed oncolytic adenovirus. J Cell Mol Med. 2015;19(5):915-923.

19. Yang Y, Xu H, Shen J, et al. RGD-modified oncolytic adenovirus exhibited potent cytotoxic effect on CAR-negative bladder cancer-initiating cells. Cell Death Dis. 2015;6(5):e1760.

20. Zhang J, Lai W, Li Q, et al. A novel oncolytic adenovirus targeting Wnt signaling effectively inhibits cancer-stem like cell growth via metastasis, apoptosis and autophagy in HCC models. Biochem Biophys Res Commun. 2017;491(2):469-477.

21. van den Hengel SK, Balvers RK, Dautzenberg IJC, et al. Heterogeneous reovirus susceptibility in human glioblastoma stem-like cell cultures. Cancer Gene Ther. 2013;20(9):507-513.

22. Allen C, Opyrchal M, Aderca I, et al. Oncolytic measles virus strains have significant antitumor activity against glioma stem cells. Gene Ther. 2013;20(4):444-449.

23. Josupeit R, Bender S, Kern S, et al. Pediatric and adult high-grade glioma stem cell culture models are permissive to lytic infection with parvovirus H-1. Viruses. 2016;8(5):E138.

24. Idema S, Geldof AA, Dirven CM, et al. Evaluation of adenoviral oncolytic effect on glioma spheroids by ${ }^{18} \mathrm{~F}$-DG positron-emission tomography. Oncol Res. 2007;16(10):471-477.

25. Lu ZZ, Wang H, Zhang Y, et al. Penton-dodecahedral particles trigger opening of intercellular junctions and facilitate viral spread during adenovirus serotype 3 infection of epithelial cells. PLoS Pathog. 2013;9(10) e1003718.

26. Israelsson S, Jonsson N, Gullberg M, Lindberg AM. Cytolytic replication of echoviruses in colon cancer cell lines. Virol J. 2011;8(1):473.
27. Israelsson S, Sävneby A, Ekström JO, Jonsson N, Edman K, Lindberg AM. Improved replication efficiency of echovirus 5 after transfection of colon cancer cells using an authentic 5' RNA genome end methodology. Invest New Drugs. 2014;32(6):1063-1070.

28. Beier R, Hermiston T, Mumberg D. Isolation of more potent oncolytic paramyxovirus by bioselection. Gene Ther. 2013;20(1):102-111.

29. Huszthy PC, Goplen D, Thorsen F, et al. Oncolytic herpes simplex virus type-1 therapy in a highly infiltrative animal model of human glioblastoma. Clin Cancer Res. 2008;14(5):1571-1580.

30. Muik A, Dold C, Geiß Y, et al. Semireplication-competent vesicular stomatitis virus as a novel platform for oncolytic virotherapy. $J \mathrm{Mol}$ Med. 2012;90(8):959-970.

31. Hong CS, Fellows W, Niranjan A, et al. Ectopic matrix metalloproteinase-9 expression in human brain tumor cells enhances oncolytic HSV vector infection. Gene Ther. 2010;17(10):1200-1205.

32. Choi IK, Lee YS, Yoo JY, et al. Effect of decorin on overcoming the extracellular matrix barrier for oncolytic virotherapy. Gene Ther. 2010;17(2):190-201.

33. Colunga A, Bollino D, Schech A, Aurelian L. Calpain-dependent clearance of the autophagy protein p62/SQSTM1 is a contributor to $\triangle \mathrm{PK}$ oncolytic activity in melanoma. Gene Ther. 2014;21(4):371-378.

34. Hu L, Sun S, Wang T, et al. Oncolytic Newcastle disease virus triggers cell death of lung cancer spheroids and is enhanced by pharmacological inhibition of autophagy. Am J Cancer Res. 2015;5(12):3612-3623.

35. Lam JT, Kanerva A, Bauerschmitz GJ, et al. Inter-patient variation in efficacy of five oncolytic adenovirus candidates for ovarian cancer therapy. J Gene Med. 2004;6(12):1333-1342.

36. Kanerva A, Zinn KR, Chaudhuri TR, et al. Enhanced therapeutic efficacy for ovarian cancer with a serotype 3 receptor-targeted oncolytic adenovirus. Mol Ther. 2003;8(3):449-458.

37. Shafren DR, Sylvester D, Johansson ES, Campbell IG, Barry RD. Oncolysis of human ovarian cancers by echovirus type 1. Int J Cancer. 2005;115(2):320-328.

38. Gil M, Komorowski MP, Seshadri M, et al. CXCL12/CXCR4 blockade by oncolytic virotherapy inhibits ovarian cancer growth by decreasing immunosuppression and targeting cancer-initiating cells. J Immunol. 2014;193(10):5327-5337.

39. Jung KH, Choi IK, Lee HS, et al. Oncolytic adenovirus expressing relaxin (YDC002) enhances therapeutic efficacy of gemcitabine against pancreatic cancer. Cancer Lett. 2017;396:155-166.

40. Kim JH, Lee YS, Kim H, Huang JH, Yoon AR, Yun CO. Relaxin expression from tumor-targeting adenoviruses and its intratumoral spread, apoptosis induction, and efficacy. J Natl Cancer Inst. 2006;98(20):1482-1493.

41. Würdinger T, Verheije $\mathrm{MH}$, Raaben $\mathrm{M}$, et al. Targeting non-human coronaviruses to human cancer cells using a bispecific single-chain antibody. Gene Ther. 2005;12(18):1394-1404.

42. Cockle JV, Brüning-Richardson A, Scott KJ, et al. Oncolytic herpes simplex virus inhibits pediatric brain tumor migration and invasion. Mol Ther Oncolytics. 2017;5:75-86.

43. Kaczorowski A, Hammer K, Liu L, et al. Delivery of improved oncolytic adenoviruses by mesenchymal stromal cells for elimination of tumorigenic pancreatic cancer cells. Oncotarget. 2016;7(8):9046-9059.

44. Kober C, Rohn S, Weibel S, Geissinger U, Chen NG, Szalay AA. Microglia and astrocytes attenuate the replication of the oncolytic vaccinia virus LIVP 1.1.1 in murine GL261 gliomas by acting as vaccinia virus traps. J Transl Med. 2015;13:216.

45. Alonso MM, Jiang H, Gomez-Manzano C, Fueyo J. Targeting brain tumor stem cells with oncolytic adenoviruses. Methods Mol Biol. 2012;797:111-125.

46. Jaime-Ramirez AC, Dmitrieva N, Yoo JY, et al. Humanized chondroitinase ABC sensitizes glioblastoma cells to temozolomide. J Gene Med. 2017;19(3):e2942.

47. Jing Y, Chavez V, Ban Y, et al. Molecular effects of stromal-selective targeting by uPAR-retargeted oncolytic virus in breast cancer. Mol Cancer Res. 2017;15(10):1410-1420. 
48. del Bufalo F, Manzo T, Hoyos V, et al. 3D modeling of human cancer: a PEG-fibrin hydrogel system to study the role of tumor microenvironment and recapitulate the in vivo effect of oncolytic adenovirus. Biomaterials. 2016;84:76-85.

49. Wadström T, Ljungh A. Glycosaminoglycan-binding microbial proteins in tissue adhesion and invasion: key events in microbial pathogenicity. J Med Microbiol. 1999;48(3):223-233.

50. Valyi-Nagy K, Dosa S, Kovacs SK, et al. Identification of virus resistant tumor cell subpopulations in three-dimensional uveal melanoma cultures. Cancer Gene Ther. 2010;17(4):223-234.

51. Voros A, Kormos B, Valyi-Nagy T, Valyi-Nagy K. Increased resistance of breast, prostate, and embryonic carcinoma cells against herpes simplex virus in three-dimensional cultures. ISRN Oncol. 2013;2013(5):104913-9.

52. Jin F, Xie Z, Kuo CJ, Chung LW, Hsieh CL. Cotargeting tumor and tumor endothelium effectively inhibits the growth of human prostate cancer in adenovirus-mediated antiangiogenesis and oncolysis combination therapy. Cancer Gene Ther. 2005;12(3):257-267.

53. Kuhn I, Bauzon M, Green N, Seymour L, Fisher K, Hermiston T. OvAd1, a novel, potent, and selective chimeric oncolytic virus developed for ovarian cancer by 3D-directed evolution. Mol The Oncolytics. 2017;4:55-66.

54. Wu X, Roberto JB, Knupp A, et al. Precision-cut human liver slice cultures as an immunological platform. J Immunol Methods. 2018;455:71-79.

55. Jakeman PG, Hills TE, Tedcastle AB, di Y, Fisher KD, Seymour LW. Improved in vitro human tumor models for cancer gene therapy. Hum Gene Ther. 2015;26(5):249-256.

56. Zimmermann M, Armeanu S, Smirnow I, et al. Human precision-cut liver tumor slices as a tumor patient-individual predictive test system for oncolytic measles vaccine viruses. Int J Oncol. 2009;34(5):1247-1256.

57. Rots MG, Elferink MG, Gommans WM, et al. An ex vivo human model system to evaluate specificity of replicating and non-replicating gene therapy agents. J Gene Med. 2006;8(1):35-41.

58. Stoff-Khalili MA, Rivera AA, Nedeljkovic-Kurepa A, et al. Cancerspecific targeting of a conditionally replicative adenovirus using mRNA translational control. Breast Cancer Res Treat. 2008;108(1):43-55.

59. Stoff-Khalili MA, Stoff A, Rivera AA, et al. Preclinical evaluation of transcriptional targeting strategies for carcinoma of the breast in a tissue slice model system. Breast Cancer Res. 2005;7(6):R1141-R1152.

60. Stoff-Khalili MA, Rivera AA, Le LP, Le P, et al. Employment of liver tissue slice analysis to assay hepatotoxicity linked to replicative and nonreplicative adenoviral agents. Cancer Gene Ther. 2006;13(6): 606-618.

61. Passer BJ, Wu CL, Wu S, Rabkin SD, Martuza RL. Analysis of genetically engineered oncolytic herpes simplex viruses in human prostate cancer organotypic cultures. Gene Ther. 2009;16(12):1477-1482.

62. Passer BJ, Cheema T, Wu S, Wu CL, Rabkin SD, Martuza RL. Combination of vinblastine and oncolytic herpes simplex virus vector expressing IL-12 therapy increases antitumor and antiangiogenic effects in prostate cancer models. Cancer Gene Ther. 2013;20(1):17-24.

63. Zhu Z, Gorman MJ, Mckenzie LD, et al. Zika virus has oncolytic activity against glioblastoma stem cells. J Exp Med. 2017;214(10): 2843-2857.

64. Potts KG, Irwin CR, Favis NA, et al. Deletion of F4L (ribonucleotide reductase) in vaccinia virus produces a selective oncolytic virus and promotes anti-tumor immunity with superior safety in bladder cancer models. EMBO Mol Med. 2017;9(5):638-654.

65. Breitbach CJ, Burke J, Jonker D, et al. Intravenous delivery of a multimechanistic cancer-targeted oncolytic poxvirus in humans. Nature. 2011;477(7362):99-102.

66. Pennington K, Chu QD, Curiel DT, Li BD, Mathis JM. The utility of a tissue slice model system to determine breast cancer infectivity by oncolytic adenoviruses. J Surg Res. 2010;163(2):270-275.

67. Stoff-Khalili MA, Stoff A, Rivera AA, et al. Gene transfer to carcinoma of the breast with fiber-modified adenoviral vectors in a tissue slice model system. Cancer Biol Ther. 2005;4(11):1203-1210.
68. Liu Y, Lang F, Xie X, et al. Efficacy of adenovirally expressed soluble TRAIL in human glioma organotypic slice culture and glioma xenografts. Cell Death Dis. 2011;2(2):e121.

69. Fulci G, Dmitrieva N, Gianni D, et al. Depletion of peripheral macrophages and brain microglia increases brain tumor titers of oncolytic viruses. Cancer Res. 2007;67(19):9398-9406.

70. Duntsch CD, Zhou Q, Jayakar HR, et al. Recombinant vesicular stomatitis virus vectors as oncolytic agents in the treatment of high-grade gliomas in an organotypic brain tissue slice-glioma coculture model. $J$ Neurosurg. 2004;100(6):1049-1059.

71. Yaacov B, Lazar I, Tayeb S, et al. Extracellular matrix constituents interfere with Newcastle disease virus spread in solid tissue and diminish its potential oncolytic activity. J Gen Virol. 2012;93(Pt 8): 1664-1672.

72. Fulci G, Passer B. Analysis of HSV oncolytic virotherapy in organotypic cultures. Methods Mol Biol. 2009;542:75-86.

73. Andrei G, Duraffour S, van den Oord J, Snoeck R. Epithelial raft cultures for investigations of virus growth, pathogenesis and efficacy of antiviral agents. Antiviral Res. 2010;85(3):431-449.

74. Durupt F, Koppers-Lalic D, Balme B, et al. The chicken chorioallantoic membrane tumor assay as model for qualitative testing of oncolytic adenoviruses. Cancer Gene Ther. 2012;19(1):58-68.

75. Heideman DA, Steenbergen RD, van der Torre J, et al. Oncolytic adenovirus expressing a p53 variant resistant to degradation by HPV E6 protein exhibits potent and selective replication in cervical cancer. Mol Ther. 2005;12(6):1083-1090.

76. Balague C, Noya F, Alemany R, Chow LT, Curiel DT. Human Papillomavirus E6E7-mediated adenovirus cell killing: selectivity of mutant adenovirus replication in organotypic cultures of human keratinocytes. J Virol. 2001;75(16):7602-7611.

77. van Zeeburg HJ, van Beusechem VW, Huizenga A, et al. Adenovirus retargeting to surface expressed antigens on oral mucosa. J Gene Med. 2010;12(4):365-376.

78. Banerjee NS, Rivera AA, Wang M, et al. Analyses of melanoma-targeted oncolytic adenoviruses with tyrosinase enhancer/promoter-driven E1A, E4, or both in submerged cells and organotypic cultures. Mol Cancer Ther. 2004;3(4):437-449.

79. Sato T, Vries RG, Snippert HJ, et al. Single Lgr5 stem cells build crypt-villus structures in vitro without a mesenchymal niche. Nature. 2009;459(7244):262-265.

80. Sato T, Stange DE, Ferrante M, et al. Long-term expansion of epithelial organoids from human colon, adenoma, adenocarcinoma, and Barrett's epithelium. Gastroenterology. 2011;141(5):1762-1772.

81. Crespo M, Vilar E, Tsai SY, et al. Colonic organoids derived from human induced pluripotent stem cells for modeling colorectal cancer and drug testing. Nat Med. 2017;23(7):878-884.

82. Gao D, Vela I, Sboner A, et al. Organoid cultures derived from patients with advanced prostate cancer. Cell. 2014;159(1):176-187.

83. Boj SF, Hwang C-I, Baker LA, et al. Organoid models of human and mouse ductal pancreatic cancer. Cell. 2015;160(1-2):324-338.

84. Broutier L, Mastrogiovanni G, Verstegen MM, et al. Human primary liver cancer-derived organoid cultures for disease modeling and drug screening. Nat Med. 2017;23(12):1424-1435.

85. Hubert CG, Rivera M, Spangler LC, et al. A three-dimensional organoid culture system derived from human glioblastomas recapitulates the hypoxic gradients and cancer stem cell heterogeneity of tumors found in vivo. Cancer Res. 2016;76(8):2465-2477.

86. Vlachogiannis G, Hedayat S, Vatsiou A, et al. Patient-derived organoids model treatment response of metastatic gastrointestinal cancers. Science. 2018;359(6378):920-926.

87. Ohlund D, Handly-Santana A, Biffi G, et al. Distinct populations of inflammatory fibroblasts and myofibroblasts in pancreatic cancer. $J$ Exp Med. 2017;214(3):579-596.

88. Tsai S, McOlash L, Palen K, et al. Development of primary human pancreatic cancer organoids, matched stromal and immune cells and 3D tumor microenvironment models. BMC Cancer. 2018;18(1):335. 
89. Ribas A, Dummer R, Puzanov I, et al. Oncolytic virotherapy promotes intratumoral $\mathrm{T}$ cell infiltration and improves anti-PD-1 immunotherapy. Cell. 2017;170(6):1109-1119.e10.

90. Shields MA, Dangi-Garimella S, Krantz SB, Bentrem DJ, Munshi HG. Pancreatic cancer cells respond to type I collagen by inducing snail expression to promote membrane type 1 matrix metalloproteinasedependent collagen invasion. J Biol Chem. 2011;286(12):10495-10504.

91. Beyer I, Li Z, Persson J, et al. Controlled extracellular matrix degradation in breast cancer tumors improves therapy by trastuzumab. Mol Ther. 2011;19(3):479-489.
92. Schäfer $\mathrm{S}$, Weibel $\mathrm{S}$, Donat U, et al. Vaccinia virus-mediated intratumoral expression of matrix metalloproteinase 9 enhances oncolysis of PC-3 xenograft tumors. BMC Cancer. 2012;12:366.

93. Verjans ET, Doijen J, Luyten W, Landuyt B, Schoofs L. Three-dimensional cell culture models for anticancer drug screening: worth the effort? J Cell Physiol. 2018;233(4):2993-3003.

94. Lin RZ, Chang HY. Recent advances in three-dimensional multicellular spheroid culture for biomedical research. Biotechnol J. 2008;3(9-10):1172-1184.

\section{Publish your work in this journal}

Oncolytic Virotherapy is an international, peer-reviewed, open access online journal publishing original research, study protocols, reviews, editorials and commentaries on all aspects of oncolytic virology, namely the application of oncolytic viruses for the treatment of cancer. Specific topics in the journal include: Rationale and theoretical aspects of oncolytic virotherapy including in vitro, in vivo and mathematical

\section{Dovepress}

modeling; and practical application and problem solving in the clinic including identification of potential responders through biomarkers and genetic profiling. The manuscript management system is completely online and includes a very quick and fair peer-review system, which is all easy to use. Visit http://www.dovepress.com/ testimonials.php to read real quotes from published authors. 